\title{
IMPACTS OF DIFFERENT AGRO-ECOLOGICAL AND MANAGEMENT PRACTICES ON THE SHRIMP PRODUCTIVITY OF Ghers IN THE SOUTHWEST COASTAL REGION OF BANGLADESH
}

\author{
K. A. Huq, M. M. Haque ${ }^{1}$, K. Mazhabuddin and S. U. Ahmed ${ }^{2}$ \\ Fisheries and Marine Resource Technology Discipline, Khulna University \\ Khulna-9208, Bangladesh
}

\begin{abstract}
The study was undertaken to investigate the impacts of water and soil quality parameters, and management practices on shrimp productivity of ghers in three agro-ecological areas of Paikgacha, Shyamnagar and Rampal in the greater Khulna district of Bangladesh. Five ghers of existing culture systems from each of three locations were selected for this study. Findings revealed that water quality parameters including salinity, alkalinity and dissolved oxygen contributed significantly $(p<0.05)$ and positively to shrimp productivity. Phytoplankton production also showed a positive correlation with shrimp productivity. Soil quality parameters including salinity, potassium and calcium content showed positive correlations with shrimp yield. In relation to management practices, stocking density, sources of PL form natural sources and supplementary feeding showed significant $(\mathrm{p}<0.05)$ and positive correlations with shrimp productivity. Water exchange also showed a positive correlation with shrimp yield.
\end{abstract}

Key Words : Agro-ecological, Gher, Correlation, Productivity

\section{INTRODUCTION}

Shrimp farming is reported one of the fastest growing economic activities in coastal areas of the Asia-Pacific region where more than $85 \%$ of world's farmed shrimp is produced and Bangladesh was the fifth largest producer in the world (FAO, 2002). The southwest coastal region of Bangladesh possesses vast and extensive brackishwater fisheries resources. Tiger shrimp (Penaeus monodon) culture in gher systems in this region plays a vital role in the fisheries sector as well as the national economy of Bangladesh. Typically, gher is a Bangle word meaning 'perimeter' and used to refer to ponds for brackishwater shrimp culture in Bangladesh. During 1996-97, approximately 80\% of total shrimp produced in gher systems in Bangladesh was exported from Khulna, Bagerhat and Satkhira districts.

The southwest coastal region of Bangladesh covers about $78 \%$ of 1,60,000 ha for shrimp culture in Bangladesh (Ahmed, 1999). Shrimp cultivation started at the beginning of the

\footnotetext{
${ }^{1}$ Department of Aquaculture, Bangladesh Agricultural University, Mymensingh-2202, Bangladesh

2 Brackishwater Station, Bangladesh Fisheries Research Institute, Paikgacha, Khulna, Bangladesh
} 
last century in the Sunderban mangrove area (Pal, 1995). However, with the increase in demand and high price of shrimp on the international market during the mid 70's, horizontal expansion of shrimp farming particularly in the southwest of the country, was rapid from the beginning of the 1980's.

With the rapid and unplanned expansion of shrimp farming, area-wise productivity levels and appropriate production technology, taking account into local agro-ecological and geological characteristics have not been considered. Shrimp farming either extensive or semi-intensive systems, flourishes well in saline and wet ecosystems where it exerts a wide range of adverse impacts (Ali, 2006). Consequently, this is attributed to the suboptimal utilization of natural resources, social constraints, environmental problems and a wide variation of shrimp yield in farming areas. Alongside these, the differences in land elevation, degree of inundation by tidal floodwaters, and salinity levels, the culture of tiger shrimp and its mode of production showed wide range of variations among areas in the southwest coastal region (Karim and Aftabuzzan, 1995).

Considering the above milieu, the factors related to the productivity level of the different systems of shrimp farming in different areas of Bangladesh are poorly understood. Islam et al. (2004) argued that environmental factors to boost aquaculture production require a basic understanding of the physical, chemical and biological processes occurring in the systems. Therefore, the current study was undertaken to investigate the impacts of water quality and other ecological factors on the productivity of shrimp farms in three agroecological zones in the greater Khulna district.

\section{MATERIALS AND METHODS}

\section{Study area}

The study was carried out in three different locations; Paikgacha, Rampal and Shyamnagar, in the greater Khulna district of Bangladesh. Five farms (ghers) from each location were selected for this study. The surface area of 15 ghers from in locations ranged from 1.07 to 7.5 hectares. The water sources of these ghers were mostly of nearby coastal rivers.

\section{Gher preparation}

The selected ghers were used for alternate shrimp-paddy culture. Paddy cultivation had been taken place during mid August to December, when salinity levels were reduced. Shrimp farming in these areas started during mid December to January when the salinity of the adjacent river started to increase. Water in the ghers was controlled by single inletoutlet. All the ghers were excavated with an internal ditch (generally called canal) of 60$100 \mathrm{~cm}$ depth adjacent to the boundary around the ghers. These ditches served to protect the cultured species during water exchange and cultivation of paddy. Water entered into the ghers through a synthetic net $(1.0 \mathrm{~mm}$ mesh) placed across the inlet to prevent the entrance of undesirable species. The bottom soil of the ghers was sun dried following the harvest of paddy with slight tilling and different level of fertilization. All of the ghers under this study were prepared for shrimp culture by the end of January. After preparation 
of ghers, both natural and hatchery produced post larvae (PL) were stocked based on their availability.

\section{Measurement of water quality parameters}

The major physico-chemical parameters of water in the selected ghers were monitored fortnightly. These were temperature, $\mathrm{pH}$ ( $\mathrm{PAL}$, Transinstrument, resolution $=0.1 \mathrm{pH}$, accuracy $= \pm 0.2 \mathrm{pH})$, salinity (ATAGO, S/MILL hand refractrometer, Salinity $=0-100$, Model-8810), Dissolved oxygen (OSK water quality checker), alkalinity (titrimetric method using standard method of APHA 1989), and transparency (Secchi disc). In addition, quantitative study of planktonic organisms was carried out using a Sedgewick Rafter (SR) counting cell.

\section{Measurement of soil quality parameters}

Soil quality parameters of ghers were investigated at the soil research laboratory in the Soil Resource Development Institute (SRDI), Khulna. The main soil quality parameters measured were salinity, $\mathrm{pH}, \mathrm{N}, \mathrm{P}, \mathrm{K}, \mathrm{Ca}, \mathrm{Mg}$, and Fe.

\section{Management practices}

The experimental ghers were managed by farmers using traditional practices. Management variables were water exchange (\%), stocking density (nos./ha), stocking of PL from hatchery (\%), stocking of PL from natural sources (\%), feeding $(\mathrm{kg} / \mathrm{ha})$, supply of organic and inorganic fertilizer $(\mathrm{kg} / \mathrm{ha})$ to the ghers.

\section{Measuring growth}

A total of 100 shrimp were sampled monthly from each gher to observe growth performance particularly length and weight of shrimp.

\section{Harvesting of shrimp}

Shrimp were harvested continuously throughout the culture period and final harvesting was conducted at the end of the culture period. Total production was the sum of the individual weights of shrimp considering their survival.

\section{Data analysis}

The data collected in this study were entered into the computer software SPSS (Version 10.0) and analyzed in accordance with the objectives of the study. To determine the relationships between shrimp productivity and possible contributing factors, correlation coefficients (r) were estimated.

\section{RESULTS AND DISCUSSION}

The correlation coefficients ( $r$ ) between shrimp productivity and water quality parameters are presented in the Table 1. The correlation coefficient between shrimp productivity and salinity was found significant $(\mathrm{p}<0.05)$ and positive. Similarly, significant correlation coefficients between shrimp production and alkalinity and 
dissolved oxygen were also found. The correlation between production and salinity may reflect the fact that salinity may play a vital role in shrimp moulting and subsequent growth performance (Chiu, 1998). The correlation between productivity and alkalinity; and productivity and dissolved oxygen; demonstrated that alkalinity and dissolved oxygen play significant role in the growth of shrimp. Significantly negative correlations between shrimp productivity and water temperature; productivity and $\mathrm{pH}$; productivity and water transparency; and productivity and zooplankton production were also observed. These results might be due to extreme fluctuations of temperature, $\mathrm{pH}$, transparency and zooplankton production disrupting the normal physiological activities of shrimp. A positive but non-significant correlation between shrimp productivity and phytoplankton production was observed, possibly a consequence of the shrimp being provided with supplementary feed.

Table 1. Correlation coefficients ( $\mathrm{r}$ ) between shrimp productivity and water quality parameters

\begin{tabular}{|c|c|c|c|c|c|c|c|c|}
\hline & $\begin{array}{l}\text { Water } \\
\text { Temp. } \\
\left({ }^{\circ} \mathrm{C}\right)\end{array}$ & $\mathrm{pH}$ & $\begin{array}{c}\text { Salinity } \\
\text { (ppt) }\end{array}$ & $\begin{array}{c}\text { Alkalinity } \\
\text { (ppm) }\end{array}$ & $\begin{array}{c}\text { Dissolve } \\
\text { oxygen } \\
\text { (mg/l) }\end{array}$ & $\begin{array}{l}\text { Water } \\
\text { transp. } \\
(\mathrm{cm})\end{array}$ & $\begin{array}{c}\text { Phytoplan. } \\
\text { production } \\
(\text { Cell/L) }\end{array}$ & $\begin{array}{c}\text { Zooplan. } \\
\text { producti } \\
\text { on } \\
\text { (Cell/L) }\end{array}$ \\
\hline \multicolumn{9}{|l|}{ Water Temp. $\left({ }^{\circ} \mathrm{C}\right)$} \\
\hline $\mathrm{pH}$ & $0.891^{* *}$ & & & & & & & \\
\hline Salinity (ppt) & $-0.980^{* *}$ & $-0.786^{* *}$ & & & & & & \\
\hline Alkalinity (ppm) & $-0.907^{* *}$ & $-0.619^{*}$ & $0.972^{* *}$ & & & & & \\
\hline Dissolve oxygen (mg/l) & $0.627^{* *}$ & $0.912^{* *}$ & $-0.463 n s$ & $-0.243 \mathrm{~ns}$ & & & & \\
\hline Water transparency $(\mathrm{cm})$ & $0.973^{* *}$ & $0.971^{* *}$ & $-0.909^{* *}$ & $-0.786^{* *}$ & $0.790^{* *}$ & & & \\
\hline $\begin{array}{l}\text { Phytoplankton } \\
\text { production (Cell/L) }\end{array}$ & $0.194 \mathrm{~ns}$ & $-0.270 \mathrm{~ns}$ & $-0.381 \mathrm{~ns}$ & $-0.587^{*}$ & $-0.641^{* *}$ & $-0.037 \mathrm{~ns}$ & & \\
\hline $\begin{array}{l}\text { Zooplankton production } \\
\text { (Cell/L) }\end{array}$ & $0.999 * *$ & $0.890^{* *}$ & $-0.981^{* *}$ & $-0.909^{* *}$ & $0.625^{* *}$ & $0.972^{* *}$ & $0.197 \mathrm{~ns}$ & \\
\hline $\begin{array}{l}\text { Shrimp productivity } \\
(\mathrm{Kg} / \mathrm{ha} / \mathrm{t})\end{array}$ & $-0.827^{* *}$ & $-0.992^{* *}$ & $0.902^{* *}$ & $0.516^{*}$ & $0.956^{* *}$ & $-0.934^{* *}$ & $0.389 \mathrm{~ns}$ & $-0.825^{* *}$ \\
\hline
\end{tabular}

$\mathrm{ns}=$ not significant; ${ }^{*}=$ significant at $5 \%$ level; ${ }^{* *}=$ significant at $1 \%$ level.

Correlation coefficients between shrimp productivity and soil quality parameters are presented in the Table 2. Positive but non-significant correlations between shrimp productivity and soil salinity; shrimp productivity and potassium content; and shrimp productivity and calcium content were found. Significant and negative correlations were found between shrimp productivity and phosphorous content; and shrimp productivity and sulpher content of the soil. Non-significant and negative correlations were observed between shrimp productivity and $\mathrm{pH}$; shrimp productivity and nitrogen content; shrimp productivity and manganese content; and shrimp productivity and iron content of the soil. 
Table 2. Correlation coefficients ( $\mathrm{r}$ ) between shrimp productivity and soil quality parameters

\begin{tabular}{|c|c|c|c|c|c|c|c|c|c|}
\hline & Salinity & $\mathrm{pH}$ & $\mathrm{N}$ & $\mathrm{P}$ & K & $S$ & $\mathrm{Ca}$ & $\mathrm{Mg}$ & $\mathrm{Fe}$ \\
\hline \multicolumn{10}{|l|}{ Salinity (Decicimen/m) } \\
\hline $\mathrm{pH}$ & $-0.855^{\star *}$ & & & & & & & & \\
\hline N (\%) & $0.600^{*}$ & $-0.812^{* *}$ & & & & & & & \\
\hline P (Microgram/g soil) & $-0.934^{* *}$ & $0.692^{* *}$ & $-0.369 n s$ & & & & & & \\
\hline $\begin{array}{l}\text { K (Mili- } \\
\text { equivalent/100g soil) }\end{array}$ & $-0.494^{*}$ & $0.605^{*}$ & $-0.250 \mathrm{~ns}$ & $0.481 \mathrm{~ns}$ & & & & & \\
\hline S (Microgram/g soil) & $-0.764^{* *}$ & $0.409 \mathrm{~ns}$ & $-0.171 n s$ & $0.841^{* *}$ & $0.012 \mathrm{~ns}$ & & & & \\
\hline $\begin{array}{l}\text { Ca (Mili- } \\
\text { equivalent/100g soil) }\end{array}$ & $0.252 \mathrm{~ns}$ & $-0.280 \mathrm{~ns}$ & $0.029 \mathrm{~ns}$ & $-0.230 \mathrm{~ns}$ & $-0.838^{* *}$ & $0.074 \mathrm{~ns}$ & & & \\
\hline $\begin{array}{l}\text { Mg (Mili- } \\
\text { equivalent/100g soil) }\end{array}$ & $-0.367 n s$ & $0.360 \mathrm{~ns}$ & $0.017 \mathrm{~ns}$ & $0.474 \mathrm{~ns}$ & $0.876^{* *}$ & $0.152 \mathrm{~ns}$ & $-0.834^{* *}$ & & \\
\hline Fe (Microgram/g soil) & $0.492^{*}$ & $-0.761^{* *}$ & $0.847^{* *}$ & $-0.207 n s$ & $-0.158 n s$ & $-0.067 \mathrm{~ns}$ & $-0.140 \mathrm{~ns}$ & $0.169 \mathrm{~ns}$ & \\
\hline $\begin{array}{l}\text { Shrimp productivity } \\
(\mathrm{kg} / \mathrm{ha} / \mathrm{t})\end{array}$ & $0.411 \mathrm{~ns}$ & $-0.013 n s$ & $-0.143 n s$ & $-0.495^{*}$ & $0.097 \mathrm{~ns}$ & $-0.778^{* *}$ & $0.070 \mathrm{~ns}$ & $-0.214 n s$ & $-0.173 n s$ \\
\hline
\end{tabular}

ns = not significant; ${ }^{*}=$ significant at $5 \%$ level; ${ }^{* *}=$ significant at $1 \%$ level.

In relation to management practices, significant $(p<0.05)$ and positive correlations were found between shrimp productivity and stocking density; shrimp productivity and source of PL from nature; and shrimp productivity and feeding (Table 3). These results show that stocking density, stocking of natural PL and providing supplementary feed were the major components of shrimp farm management practices. The degree of stocking density to an extent influences the productivity of prawn (Haque et al., 2003). In this study, quality of seed in terms of their origin in natural source also played an important role in the growth and production of shrimp, which is corroborated by a previous study conducted by Chanratchakool et al. (1995).

The correlation between shrimp productivity and feeding was found highly significant $(\mathrm{p}<0.05)$, indicating that feeding was the most important part of management practices in gher culture. A non-significant positive correlation was observed between shrimp productivity and water exchange rate. In semi-intensive shrimp culture systems, regular water exchange dilutes toxic substances and protects planktonic blooms developing in the gher. Low rate of water exchange may cause inhibition of growth and moulting in shrimp and environmental degradation (Chanratchakool et al., 1998).

A significantly negative correlation was observed between shrimp productivity and sources of post larvae. The quality of shrimp seed is affected by traditional hatchery management practices, transportation and acclimatization (Chanratchakool et al., 1998). Significantly negative correlations were also observed between shrimp productivity and fertilization irrespective of both organic and inorganic fertilizers. This was possibly due 
to the nutritional contribution to the yield mostly drawn from supplementary feeding (Paul and Khondoker, 1996).

Table 3. Correlation coefficients (r) between shrimp production and management aspects

\begin{tabular}{l|c|c|c|c|c|c|c}
\hline & $\begin{array}{c}\text { Water } \\
\text { exchange } \\
(\%)\end{array}$ & $\begin{array}{c}\text { Sticking } \\
\text { density } \\
(\text { Nos./ha) }\end{array}$ & $\begin{array}{c}\text { PL from } \\
\text { hatchery } \\
(\%)\end{array}$ & $\begin{array}{c}\text { PL from } \\
\text { nature }(\%)\end{array}$ & $\begin{array}{c}\text { Feed } \\
(\mathrm{kg} / \mathrm{ha})\end{array}$ & $\begin{array}{c}\text { Organic } \\
\text { fertilizer } \\
(\mathrm{kg} / \mathrm{ha})\end{array}$ & $\begin{array}{c}\text { Inorganic } \\
\text { fertilizer } \\
(\mathrm{Kg} / \mathrm{ha})\end{array}$ \\
\hline Water exchange (\%) & & & & & & \\
Sticking density (Nos./ha) & $0.056 \mathrm{~ns}$ & & & & & & \\
PL from hatchery (\%) & $-0.315 \mathrm{~ns}$ & $-0.118 \mathrm{~ns}$ & & & & & \\
PL from Nature (\%) & $0.328 \mathrm{~ns}$ & $0.070 \mathrm{~ns}$ & $-0.997^{* *}$ & & & & \\
Feed (kg/ha) & $0.284 \mathrm{~ns}$ & $0.366 \mathrm{~ns}$ & $-0.603^{*}$ & $0.603^{*}$ & & & \\
Organic fertilizer (kg/ha) & $-0.427 \mathrm{~ns}$ & $-0.357 \mathrm{~ns}$ & $0.478 \mathrm{~ns}$ & $-0.483 \mathrm{~ns}$ & $-0.961^{* *}$ & & \\
Inorganic fertilizer (Kg/ha) & $-0.550^{*}$ & $-0.284 \mathrm{~ns}$ & $0.469 \mathrm{~ns}$ & $-0.478 \mathrm{~ns}$ & $-0.927^{* *}$ & $0.976^{* *}$ & \\
$\begin{array}{l}\text { Shrimp productivity } \\
\text { (Kg/ha/t) }\end{array}$ & $0.146 \mathrm{~ns}$ & $0.537^{*}$ & $-0.583^{*}$ & $0.577^{*}$ & $0.917^{* *}$ & $-0.840^{* *}$ & $-0.766^{* *}$ \\
\hline
\end{tabular}

ns = not significant; ${ }^{*}=$ significant at $5 \%$ level; ${ }^{* *}=$ significant at $1 \%$ level.

In Bangladesh most of the shrimp farms are based on traditional farming patterns where overall management practices are very poor. This study attempted to determine the effect of physico-chemical aspects of soil and water, water exchange, stocking density, use of fertilizer and supplementary feed on shrimp production. Gher farmers could be suggested to increase their awareness on these factors discussed above so that they could increase the productivity of their shrimp farms maintaining better aquatic environment.

\section{REFERENCES}

Ahmed, S. U. 1999. Research needs for sustainable shrimp culture development with special reference to health management. In : Paper presented in national seminar on "Disease Prevention and Health Management in Coastal Shrimp Culture in Bangladesh". April 13-15'1999. Department of Fisheries, Ministry of Fisheries and Livestock, Bangladesh in collaboration with FAO of the United Nations.

Ali, A. M. S. 2006. Rice to shrimp: Land use/land cover changes and soil degradation in Southwestern Bangladesh. Land Use Policy, 23(4) : 421-435.

Chanratchakool, P., Turnbull, J. F., Funge-Smith, S. and Limsuwan, C. 1995. Health Management in Shrimp Ponds. Aquatic Animal Health Research Institute. Department of Fisheries, Kasetsart University Campus, Bangkok, Thailand. Second Edition. pp. 2-58.

Chanratchakool, P., Turnbull, J. F., Funge-Smith, S. and Limsuwan, C. 1998. Health Management in Shrimp Ponds (3rd edn.). Aquatic Animal Health Research Institute. Dept. Fisheries. Bangkok-10900. Thailand. p. 152.

Chiu, Y. M. 1988. Consideration for Planning Farm Projects. In : Technical consideration for the Mnagement and Operation of Intensive Prawn Farms (eds. Y. M. Chiu, L. M. Santose and R.O. Juliano). U. P. Aquaculture Sociaty. Iloilo City. Philippines. pp. 25-28.

FAO, 2002. FAO yearbook of Fishery Statistics, Aquaculture Production, vol. 90/2. Food and Agricultural Organization of the United Nations, Rome, Italy. 
Haque M. M., Narejo, N. T., Salam, M. A., Rahmatullah, S. M. and Islam, M. A. 2003. Determination of optimum stocking density of Macrobrachium rosenbergii in carp polyculture in earthen pond. Pakistan J. Biol. Sci., 6(10) : 898-901.

Karim, M and Aftabuzzaman, 1997. Brackish and marine water aquaculture: Potential, Constraints and Management Needs for Sustainable Development. In : Proceedings of the National workshop on fisheries resource development and management in Bangladesh held at Dhaka Oct. 29 -Nov. 1, 1995. The ministry of fisheries and livestock, Bangladesh in collaboration with BOBP/FAO and ODA. Published by Bangladesh Agricultural Research Council, 119 pp.

Pal, S. K. 1995. Shrimp Biology and Culture Management. A Bengali text named 'Chingri jib-biddha ebang chash babasthapana', pp. 132-137.

Paul, S. C and Khondoker, H. R. 1996. Manual for Culture and Management of P. monodon in semiintensive farms (in Bangla). Department Fisheries. Bangladesh. $14 \mathrm{p}$.

Islam, M. S., Sarker, M. J., Yamamoto, T., Wahab, M. A. and Tanaka, M. 2004. Water and sediment quality, partial mass budget and effluent $\mathrm{N}$ loading in coastal brackishwater shrimp farms in Bangladesh. Marine Poll. Bullet., 48 (5-6) : 471-485. 